\title{
Performance evaluation of a control strategy for photosynthetic biogas upgrading in a semi-industrial scale photobioreactor
}

\author{
María del Rosario Rodero ${ }^{\mathrm{a}, \mathrm{b}}$, Andrea Carvajal ${ }^{\mathrm{a}, \mathrm{c}}$, Zouhayr Arbib ${ }^{\mathrm{d}}$, Enrique Lara ${ }^{\mathrm{d}}$, César de Prada ${ }^{\mathrm{b}}$, \\ Raquel Lebrero ${ }^{\mathrm{a}, \mathrm{b}}$, Raúl Muñoz ${ }^{\mathrm{a}, \mathrm{b}, *}$ \\ a Department of Chemical Engineering and Environmental Technology, University of Valladolid, Dr. Mergelina s/n., Valladolid 47011, Spain \\ ${ }^{\mathrm{b}}$ Institute of Sustainable Processes, University of Valladolid, 47011 Valladolid, Spain \\ c Departamento de Ingeniería Química y Ambiental, Universidad Técnica Federico Santa María, Av. España, 1680 Valparaíso, Chile \\ d FCC Servicios Ciudadanos, Av. del Camino de Santiago, 40, edificio 3, 4 ${ }^{a}$ planta, 28050 Madrid, Spain
}

\section{A R T I C L E I N F O}

\section{Keywords}

Algal-bacterial processes

Biogas upgrading

Biomethane

Process control

Semi-industrial scale

\begin{abstract}
A B S T R A C T
The validation of a control strategy for biogas upgrading via light-driven $\mathrm{CO}_{2}$ consumption by microalgae and $\mathrm{H}_{2} \mathrm{~S}$ oxidation by oxidizing bacteria using the oxygen photosynthetically generated was performed in a semi-industrial scale $\left(9.6 \mathrm{~m}^{3}\right)$ photobioreactor. The control system was able to support $\mathrm{CO}_{2}$ concentrations lower than $2 \%$ with $\mathrm{O}_{2}$ contents $\leq 1 \%$ regardless of the $\mathrm{pH}$ in the cultivation broth (ranging from 9.05 to 9.50). Moreover, the control system was efficient to cope with variations in biogas flowrate from 143 to $420 \mathrm{~L} \mathrm{~h}^{-1}$, resulting in a biomethane composition of $\mathrm{CO}_{2}<2.4 \%, \mathrm{CH}_{4}>95.5 \%, \mathrm{O}_{2}<1 \%$ and no $\mathrm{H}_{2} \mathrm{~S}$. Despite the poor robustness of this technology against failures in biogas and liquid supply $\left(\mathrm{CH}_{4}\right.$ concentration of 67.5 and $70.9 \%$ after $2 \mathrm{~h}$ of biogas or liquid stoppage, respectively), the control system was capable of restoring biomethane quality in less than $2 \mathrm{~h}$ when biogas or liquid supply was resumed.
\end{abstract}

\section{Introduction}

Biogas from the anaerobic digestion of the organic matter present in solid waste, wastewater or energy crops constitutes a valuable source of renewable energy. This green gas can be used for heat and/or power generation due to its high $\mathrm{CH}_{4}$ content (50-75\%) (Surendra et al., 2014). Nevertheless, the presence of contaminants such as $\mathrm{CO}_{2}$ (30-50\%) and $\mathrm{H}_{2} \mathrm{~S}(0.005-2 \%)$ hinders the widespread use of this sustainable energy vector (Ryckebosch et al., 2011). In this regard, the removal of $\mathrm{CO}_{2}$ reduces biogas transportation and compression costs and increases its specific calorific value (Yan et al., 2016). On the other hand, $\mathrm{H}_{2} \mathrm{~S}$ removal is required since it is a hazardous and corrosive gas that promotes emissions of sulfur oxides $\left(\mathrm{SO}_{\mathrm{x}}\right)$ during combustion (Brito et al., 2017). In this context, biogas upgrading is a mandatory step to enable its use as vehicle fuel or its injection into natural gas grids, which requires concentrations in biogas of $\mathrm{CH}_{4} \geq 90 \%$, $\mathrm{CO}_{2} \leq 2-4 \%, \mathrm{O}_{2} \leq 1 \%$ and trace levels of $\mathrm{H}_{2} \mathrm{~S}$ according to most international regulations (Muñoz et al., 2015). The recast Renewable Energy Directive (RED II) sets an overall EU target to achieve at least a $32 \%$ consumption of energy from renewable sources by 2030 , which includes an annual increase of $1.3 \%$ in the share of renewable energy in the heating sector and the use of a minimum of $14 \%$ renewable energy in the transport sector by 2030 (Directive (EU) (2018)/2001, 2018). Therefore, biomethane has become increasingly attractive in Europe during the past years, where the number of biogas upgrading plants has increased from 187 to 540 in the 2011-2017 period, with a biomethane production up to 19352 GWh in 2017 (EBA, 2018). However, a cost-competitiveness and sustainable biogas upgrading technology is still necessary to boost the use of this promising energy source.

Nowadays, physicochemical methods such as water/organic/chemical scrubbing, pressure swing absorption and membrane separation for $\mathrm{CO}_{2}$ removal are widely applied for biogas upgrading (EBA, 2018). However, these technologies often need a previous $\mathrm{H}_{2} \mathrm{~S} /$ siloxane $/ \mathrm{H}_{2} \mathrm{O}$ abatement step and exhibit a high energy and chemical demand that jeopardize the environmental and economic feasibility of biomethane (Awe et al., 2017). On the other hand, biological biogas upgrading require a two-step process (microaerobic digestion or biofiltration for $\mathrm{H}_{2} \mathrm{~S}$ removal followed by hydrogenotrophic $\mathrm{CO}_{2}$ bioconversion into $\mathrm{CH}_{4}$ ) and a surplus of electricity from renewable sources (to produce the $\mathrm{H}_{2}$ required for microbial $\mathrm{CO}_{2}$ reduction) (Angelidaki et al., 2018; Muñoz et al., 2015). In this context, photosynthetic biogas upgrading is an attractive alternative for the concomitant and cost-competitive removal of $\mathrm{CO}_{2}$ and $\mathrm{H}_{2} \mathrm{~S}$ from biogas (Nagarajan et al., 2019). This process is based on the fixation of $\mathrm{CO}_{2}$ by microalgae in the presence of light and the oxidation of $\mathrm{H}_{2} \mathrm{~S}$ to $\mathrm{S}^{0} / \mathrm{SO}_{4}{ }^{2-}$ by sulfur-

\footnotetext{
* Corresponding author at: Department of Chemical Engineering and Environmental Technology, University of Valladolid, Dr. Mergelina s/n., Valladolid 47011, Spain.

E-mail address: mutora@iq.uva.es (R. Muñoz)
} 
oxidizing bacteria using the oxygen produced by microalgal photosynthesis (Sun et al., 2016). Moreover, digestate from anaerobic digestion, a nutrient-rich effluent from the process, can be used as $\mathrm{N}$ and $\mathrm{P}$ source to support microalgal/bacterial growth, which improves the environmental and economic sustainability of this green technology (Ouyang et al., 2015).

The optimization of photosynthetic biogas upgrading coupled with nutrient recovery from digestates, which is commonly implemented in a bubble biogas scrubbing column (AC) interconnected via culture broth recirculation to a photobioreactor where the absorbed $\mathrm{CO}_{2}$ and $\mathrm{H}_{2} \mathrm{~S}$ uptake occurs, has been carried out under indoors conditions at lab scale (Bahr et al., 2014; Franco-Morgado et al., 2017; Meier et al., 2018; Rodero et al., 2018; Serejo et al., 2015). Nevertheless, the performance of outdoors systems is governed by the daily and seasonal variations in environmental conditions, the $\mathrm{pH}$ in the cultivation broth being a critical parameter that impacts on both $\mathrm{H}_{2} \mathrm{~S}$ and $\mathrm{CO}_{2}$ gas-liquid mass transfer in the AC (Bose et al., 2019; Posadas et al., 2017). In addition, the efficiency of the upgrading process could be affected by variations in the daily production and composition of biogas, process shutdowns or technical failures in equipment. In this regard, del Rodero et al. (2019) designed a control system to cope with possible disturbances during photosynthetic biogas upgrading based on the optimization of the liquid to biogas ratio (L/G), which is a key factor determining the $\mathrm{CO}_{2}$ and $\mathrm{H}_{2} \mathrm{~S}$ absorption in the AC (Meier et al., 2019). The control system was systematically evaluated in a $180 \mathrm{~L}$ high rate algal pond (HRAP) interconnected to an AC under indoors conditions with promising results under most conditions tested (biomethane composition of $\mathrm{O}_{2}<1 \%$ and $\mathrm{CO}_{2}<2.5 \%$ and $\mathrm{CH}_{4}>94 \%$ ) (Rodero et al., 2019). However, the validation of any control strategy at a demo scale under outdoors conditions is a requirement prior full-scale implementation of this technology.

This study constitutes, to the best of our knowledge, the first evaluation under outdoors conditions and semi-industrial scale of the performance of a control system devoted to maintain or restore biomethane quality under environmental variations (different $\mathrm{pH}$ of the cultivation broth, daily biogas production fluctuations) or operational failures during photosynthetic biogas upgrading.

\section{Materials and methods}

\subsection{Experimental set-up}

The experimental set-up was composed of a $9.6 \mathrm{~m}^{3}$ HRAP with an illuminated surface of $32 \mathrm{~m}^{2}$ and a depth of $0.3 \mathrm{~m}$, interconnected to a $7 \mathrm{~m}^{3}$ conical settler prior to a $150 \mathrm{~L}$ biogas AC via an external recirculation of the cultivation broth. The system was operated outdoors during summer conditions (average ambient temperature and light radiance of $24.2 \pm 2.0{ }^{\circ} \mathrm{C}$ and $25.5 \pm 1.3 \mathrm{MJ} \mathrm{m}^{-2} \mathrm{~d}^{-1}$, respectively) at Chiclana de la Frontera WWTP $\left(36.42^{\circ} \mathrm{N}, 6.15^{\circ} \mathrm{W}\right)$ (Spain). The HRAP consisted of two water channels divided by a central wall made of concrete blocks and two flow rectifiers in each loop to avoid dead zones, backflow and eddies (de Godos et al., 2016). The HRAP was continuously agitated at an internal liquid recirculation velocity of $\approx 30 \mathrm{~cm} \mathrm{~s}^{-1}$ by a 6-blade paddlewheel. The average composition of the real centrate, fed at a flow rate of $160 \mathrm{~L} \mathrm{~d}^{-1}$, was $\left(\mathrm{mg} \mathrm{L}^{-1}\right)$ : alkalinity $\left(\mathrm{CaCO}_{3}\right)=2420 \pm 192$, chemical oxygen demand $(\mathrm{COD})=793 \pm 214$, total nitrogen $(\mathrm{TN})=724 \pm 118$, ammonium $\left(\mathrm{N}-\mathrm{NH}_{4}{ }^{+}\right)=579 \pm 27$, phosphate $\left(\mathrm{P}^{-} \mathrm{PO}_{3}{ }^{4-}\right)=60 \pm 17$ and volatile suspended solids (VSS) $=320 \pm 248$. The inorganic carbon (IC) concentration of the HRAP cultivation broth was adjusted to $1907 \pm 109 \mathrm{mg} \mathrm{L}^{-1}$ by addition of $\mathrm{NaHCO}_{3}$ and $\mathrm{Na}_{2} \mathrm{CO}_{3}$.

The algal-bacterial biomass was harvested from the bottom of the settler at a rate providing a fixed biomass productivity of $30 \mathrm{~g} \mathrm{~m}^{-2} \mathrm{~d}^{-1}$
. The algal-bacterial biomass was continuously produced (from $\mathrm{CO}_{2}, \mathrm{H}_{2} \mathrm{~S}$ and nutrient fixation) and harvested, with a fraction being recirculated. This process, and the stability of the algal-bacterial biomass, was confirmed during a recent one-year round evaluation of the technology conducted by the authors (Marín et al., 2018).

Biogas, obtained from the anaerobic digestion of sewage sludge in a $20 \mathrm{~m}^{3}$ digester located at Chiclana de la Frontera WWTP, was sparged into the AC using a polypropylene fine bubble diffuser (ECOTEC, Spain) under countercurrent flow configuration with the clarified cultivation broth (pumped from the top of the settler). Raw biogas composition was $70.5 \pm 1.7 \% \mathrm{CH}_{4}, 31.5 \pm 1.1 \% \mathrm{CO}_{2}$ and $52 \pm 57 \mathrm{ppm} \mathrm{H}_{2} \mathrm{~S}$. The low content of $\mathrm{H}_{2} \mathrm{~S}$ in the inlet biogas was mediated by the pretreatment performed to the sewage sludge prior anaerobic digestion. Biogas composition $\left(\mathrm{CO}_{2}, \mathrm{CH}_{4}, \mathrm{O}_{2}\right.$ and $\left.\mathrm{H}_{2} \mathrm{~S}\right)$ was measured using an online gas analyzer INCA 4001 (UNION Instruments $\mathrm{GmbH}$, Germany). The resolution of the sensors of the biogas analyzer was 0.1 vol\% for $\mathrm{CO}_{2}, \mathrm{O}_{2}$ and $\mathrm{CH}_{4}$ and $1 \mathrm{ppm}_{\mathrm{v}}$ in the case of $\mathrm{H}_{2} \mathrm{~S}$. The range of measurement was $0-100 \mathrm{vol} \%$ for $\mathrm{CO}_{2}$ and $\mathrm{CH}_{4}, 0-25$ vol\% for $\mathrm{O}_{2}$ and $0-10000 \mathrm{ppm}_{\mathrm{v}}$ for $\mathrm{H}_{2} \mathrm{~S}$, while the accuracy was $\pm 1 \%, \pm 1 \%, \pm 3 \%$ and $\pm 10 \%$ of the range for $\mathrm{CO}_{2}$, $\mathrm{CH}_{4}, \mathrm{O}_{2}$ and $\mathrm{H}_{2} \mathrm{~S}$, respectively. The control module was composed of a Programmable Logic Controller (PLC) "S7-315" via an interface developed using the software Human Machine Interface (HMI) Scada "WinCC Flexible 2008 SP4" (Siemens). The pH of the recycling liquid was measured using a Crison pH 4603 probe coupled to a Crison Multimeter 44 display (Barcelona, Spain). The concentration of dissolved IC in the cultivation broth was determined by means of a Shimadzu TOC-VCSH analyzer (Japan) equipped with a TNM-1 chemiluminescence module.

\subsection{Control system strategy}

A rule-based control system was implemented in order to maintain a biomethane quality over time according to the results reported by del Rodero et al. (2019) during the evaluation of the control system under lab scale indoors conditions. The controlled variables were the $\mathrm{O}_{2}$ and $\mathrm{CO}_{2}$ concentration in the biomethane, while the manipulated variable was the recycling liquid flow rate, which consequently modified the $\mathrm{L} / \mathrm{G}$ ratio in the AC. A set point value of $2 \%$ and $1 \%$ were set for $\mathrm{CO}_{2}$ and $\mathrm{O}_{2}$ concentrations, respectively, in order to comply with the target values for biomethane use as natural gas substitute in most international legislations (including the recent European Standard UNE-EN 16723). The $\mathrm{O}_{2}$ content in biomethane was also selected as controlled variable since a high $\mathrm{O}_{2}$ desorption in the AC can result in explosive gas mixtures (Di Benedetto et al., 2011). On the contrary, the $\mathrm{CH}_{4}$ content in the upgraded biogas was not chosen as controlled variable since negligible losses are typically accounted as a result of its low aqueous solubility, while $\mathrm{H}_{2} \mathrm{~S}$ content was not considered either based on the higher $\mathrm{H}_{2} \mathrm{~S}$ removal efficiencies (REs) associated to the superior $\mathrm{H}_{2} \mathrm{~S}$ aqueous solubility compared to $\mathrm{CO}_{2}$.

The control system operated based on the differences between the $\mathrm{O}_{2}$ and $\mathrm{CO}_{2}$ concentration measured in the upgraded biogas and the set point values fixed, the changes implemented in the recycling liquid flowrate being summarized in Table 1 . When the $\mathrm{O}_{2}$ content in the upgraded biogas was $>1 \%$, the pump flow rate was decreased due to safety reasons even if the $\mathrm{CO}_{2}$ content in the upgraded biogas was $>2 \%$ (set point value). When the $\mathrm{O}_{2}$ content in the biomethane was $<1 \%$ and $\mathrm{CO}_{2}$ content $>2 \%$, the control system increased the flow rate of the recycling liquid pump in order to enhance the $\mathrm{CO}_{2}$ gas-liquid mass transfer. Finally, when the $\mathrm{O}_{2}$ content in the biomethane was $<1 \%$ and $\mathrm{CO}_{2}$ content $<2 \%$, thus complying with the standard values, the flow rate of the recycling liquid pump was also decreased in order to save energy. 
Table 1

Variations in the recycling liquid flowrate as a function of the differences between the concentrations of $\mathrm{CO}_{2}$ and $\mathrm{O}_{2}$ in the biomethane and the set point values $\left(\Delta \mathrm{CO}_{2}\right.$ and $\Delta \mathrm{O}_{2}$, respectively).

\begin{tabular}{|c|c|c|c|}
\hline$\Delta \mathrm{O}_{2}$ & $\Delta \mathrm{CO}_{2}$ & $\begin{array}{l}\text { Power } \\
\text { pump } \\
\text { variation } \\
(\%)\end{array}$ & $\begin{array}{l}\text { Liquid } \\
\text { flow rate } \\
\text { variation } \\
\left(\mathrm{L} \mathrm{h}^{-1}\right)\end{array}$ \\
\hline \multirow[t]{10}{*}{$\leq 0$} & {$[(-2)-(-1)]$} & -6 & -45.2 \\
\hline & {$[(-1)-(-0.5)$} & -4 & -30.1 \\
\hline & ] & & \\
\hline & {$[(-0.5)-0]$} & -2 & -15.1 \\
\hline & [0-0.5] & 5 & 37.6 \\
\hline & [0.5-1] & 10 & 75.3 \\
\hline & [1-5] & 15 & 112.9 \\
\hline & [5-10] & 20 & 150.5 \\
\hline & [10-20] & 25 & 188.2 \\
\hline & $>20$ & 30 & 225.8 \\
\hline$[0-0.5]$ & & -5 & -37.6 \\
\hline [0.5-1] & & -10 & -75.3 \\
\hline [1-5] & & -15 & -112.9 \\
\hline$>5$ & & -20 & -150.5 \\
\hline
\end{tabular}

\subsection{Validation of the control strategy}

The performance of the proposed control strategy was evaluated under different $\mathrm{pH}$ values in the cultivation broth $(9.05,9.20,9.35,9.50)$ for $8 \mathrm{~h}$ when the system operated under steady state. The initial L/G ratio was 0.8 (corresponding to the lowest $\mathrm{L} / \mathrm{G}$ ratio that could be reached in the demo experimental set-up).

Process response to the stepwise variations in biogas flowrate (every $1 \mathrm{~h}$ and $20 \mathrm{~min}$ ) from $143 \mathrm{~L} \mathrm{~h}^{-1}$ to 218,300 and 420 , and back to $143 \mathrm{~L} \mathrm{~h}^{-1}$, was tested under controlled and uncontrolled conditions. The inlet $\mathrm{pH}$ of the cultivation broth in the AC was 9.20 and the initial liquid flowrate was maintained at $327 \mathrm{~L} \mathrm{~h}^{-1}$ (minimum value) during the uncontrolled conditions.

Finally, the robustness of the technology towards operational failures in biogas supply and in the liquid recirculation was assessed. After process monitoring for $4 \mathrm{~h}$ under steady state, the biogas compressor or the recycling liquid pump were turned off for $2 \mathrm{~h}$, and subsequently switched on again followed by process monitoring for the next $4 \mathrm{~h}$ under controlled and uncontrolled conditions. During the robustness test, the inlet $\mathrm{pH}$ of the cultivation broth in the AC was 9.35, the biogas flowrate was set at $420 \mathrm{~L} \mathrm{~h}^{-1}$ and the initial $\mathrm{L} / \mathrm{G}$ was fixed based on the minimum $\mathrm{L} / \mathrm{G}$ ratio able to provide a satisfactory biomethane quality $\left(\mathrm{CO}_{2}\right.$ content $\leq 2 \%$ ) under these operational conditions ( $\mathrm{L} / \mathrm{G} \approx 1.1-1.2$ ).

In all experiments, the composition of the upgraded biogas was measured every $20 \mathrm{~min}$ prior actuation of the control system.

\section{Results and discussion}

\subsection{Evaluation of process performance under different $\mathrm{pH}$ in the cultivation} broth

The effect of the $\mathrm{pH}$ of the cultivation broth on the performance of photosynthetic biogas upgrading was evaluated. The upgraded biogas composition, $\mathrm{L} / \mathrm{G}$ ratios and recycling liquid $\mathrm{pH}$ at the outlet of the AC under uncontrolled (initial values) and controlled conditions at different pHs of the cultivation broth $(9.5,9.35,9.2$ and 9.05) are shown in
Fig. 1. In this regard, a slight drop in the $\mathrm{pH}$ of the cultivation broth $(\sim 0.15)$ caused a remarkable decrease in the $\mathrm{CO}_{2}$ gas-liquid mass transfer in the AC under uncontrolled conditions despite the high alkalinity of the cultivation broth $\left(1907 \pm 109 \mathrm{mg} \mathrm{IC} \mathrm{L}{ }^{-1}\right)$. The $\mathrm{CO}_{2}$ concentration in the upgraded biogas increased from $2.7 \pm 0.1$ to $4.9 \pm 0.1,9.7 \pm 0.1$ and $12.0 \pm 0.0 \%$, which corresponded to $\mathrm{CO}_{2}$ - $\mathrm{REs}$ of $93.4,87.7,77.9$ and $68.5 \%$, at a $\mathrm{pH}$ of $9.50,9.35,9.20$ and 9.05 , respectively, exceeding the $\mathrm{CO}_{2}$ set point value $(2 \%)$ at a $\mathrm{L} / \mathrm{G}$ ratio of 0.8 (Fig. 1a). These results agreed with those reported in a pilot scale HRAP by Bahr et al. (2014), who obtained $\mathrm{CO}_{2}$-REs $<50 \%$ at a $\mathrm{pH}$ of 9 and a $\mathrm{L} / \mathrm{G}$ ratio of 0.4 and $\mathrm{CO}_{2}$-REs $>90 \%$ at a pH of 10 . Likewise, del Rodero et al. (2019) recorded $\mathrm{CO}_{2}$ concentrations in the upgraded biogas $<2 \%$ and $16 \%$ at a $\mathrm{pH}$ of 10 and 8.5 , respectively, under similar conditions (L/G ratio of 0.5 and $1500 \mathrm{mg} \mathrm{IC} \mathrm{L}^{-1}$ in the cultivation broth). In this context, dissolved inorganic carbon in water is a mixture of $\mathrm{CO}_{2}$ (aq), $\mathrm{HCO}_{3}{ }^{-}$and $\mathrm{CO}_{3}{ }^{2-}$, the dissociation constants being $\mathrm{pka}_{1}=6.35$ and $\mathrm{pka}_{2}=10.3$ at $25{ }^{\circ} \mathrm{C}$ (Lee and Pirt, 1984). In our particular study, the dissolved inorganic carbon in the liquid phase was composed of $\mathrm{HCO}_{3}{ }^{-}$(main species) and $\mathrm{CO}_{3}{ }^{2-}$ in the range of $\mathrm{pH}$ tested (9.05-9.50). In this specific range, a slight increase in $\mathrm{pH}$ of 0.15 shifted the equilibrium towards more $\mathrm{CO}_{3}{ }^{2-}$ formation, thus increasing the $\mathrm{CO}_{2}$ gas-liquid concentration gradient, and consequently higher $\mathrm{CO}_{2}$ removals were achieved.

On the other hand, a complete $\mathrm{H}_{2} \mathrm{~S}$ removal was achieved regardless of the $\mathrm{pH}$ of the cultivation broth as a result of its higher aqueous solubility compared to $\mathrm{CO}_{2}$ (according to Henry's dimensionless constant) and low concentration in the inlet biogas (52 $\pm 57 \mathrm{ppm}_{\mathrm{v}}$ of $\mathrm{H}_{2} \mathrm{~S}$ ) (Sander, 1999). Moreover, since the sulfide dissociation constants are $\mathrm{pka}_{1}=7.04$ and $\mathrm{pka}_{2}=11.95$ at $18{ }^{\circ} \mathrm{C}$ (Smet et al., 1998), the predominant species in the liquid phase in the range of $\mathrm{pH}$ studied (9.05-9.50) was $\mathrm{HS}^{-}$, thus increasing the $\mathrm{H}_{2} \mathrm{~S}$ gas-liquid concentration gradient and consequently the mass transfer. In this context, Kang et al. (2020) observed a rapid increase in the aqueous $\mathrm{H}_{2} \mathrm{~S}$ concentration at $\mathrm{pH} 10$ due to the 100 times higher $\mathrm{H}_{2} \mathrm{~S}$ equilibrium aqueous concentration in comparison with that at $\mathrm{pH}$ 8. On the other hand, the oxidation of HS $^{-}$in the liquid phase can be chemical (supported by the high dissolved oxygen in the cultivation broth) and/or biological (by sulfur-oxidizing bacteria, i.e. Thioalbus genus) (Meier et al., 2018; Toledo-Cervantes et al., 2016). In this regard, although sulfur oxidation can result in different products $\left(\mathrm{S}^{0}, \mathrm{~S}_{2} \mathrm{O}_{3}{ }^{2-}\right.$ and $\left.\mathrm{SO}_{4}{ }^{2-}\right), \mathrm{SO}_{4}{ }^{2-}$ is typically the major end-product due to the high dissolved oxygen (up to $21.6 \mathrm{mg} \mathrm{\textrm {O } _ { 2 }}$ $\mathrm{L}^{-1}$ ) and $\mathrm{pH}$ in the cultivation broth of algal-bacterial photobioreactors (Kang et al., 2020; Meier et al., 2018).

Consequently, the $\mathrm{CH}_{4}$ concentration in the upgraded biogas accounted for $97.3 \pm 0.1,95.1 \pm 0.1,90.3 \pm 0.1$ and $88.0 \pm 0.0 \%$ at a $\mathrm{pH}$ of 9.50, 9.35, 9.20 and 9.05, respectively, under uncontrolled conditions, while $\mathrm{O}_{2}$ concentration in the upgraded biogas was always negligible due to the low initial $\mathrm{L} / \mathrm{G}$ ratio (0.8) (Fig. 1). In this regard, Toledo-Cervantes et al. (2017) recorded a slightly higher $\mathrm{O}_{2}$ desorption in the upgraded biogas $\left(\mathrm{O}_{2}\right.$ content $\left.\sim 0.8 \%\right)$ under counter-current operation at a $\mathrm{L} / \mathrm{G}$ ratio of 0.8 (similar conditions to this study), while the $\mathrm{O}_{2}$ content was almost zero under co-current operation.

When the control system was initiated, the $\mathrm{CO}_{2}$ concentration decreased to values lower than the set point (2\%) after $1 \mathrm{~h}$ at the highest $\mathrm{pH}$ (9.50) and $2 \mathrm{~h}$ at the lowest (9.05), and remained stable afterwards (Fig. 1a). No $\mathrm{H}_{2} \mathrm{~S}$ concentration was detected in the upgraded biogas regardless of the $\mathrm{pH}$. Interestingly, the $\mathrm{O}_{2}$ concentrations in the biomethane were higher when the control was active compared to those without control as a result of the higher L/G ratios in the AC. However, these concentrations remained below the set point $\left(\mathrm{O}_{2}\right.$ concentration $=1 \%$ ) in most of the experiments except at a $\mathrm{pH}$ of 9.05, where a maximum $\mathrm{O}_{2}$ concentration of $1 \%$ was achieved (Fig. 1b). Maximum L/G ratios of 1.3, 1.7, 2.1 and 2.4 , which corresponded to liquid flowrates of 515, 681, 816 and $967 \mathrm{~L} \mathrm{~h}^{-1}$, were recorded at a $\mathrm{pH}$ 

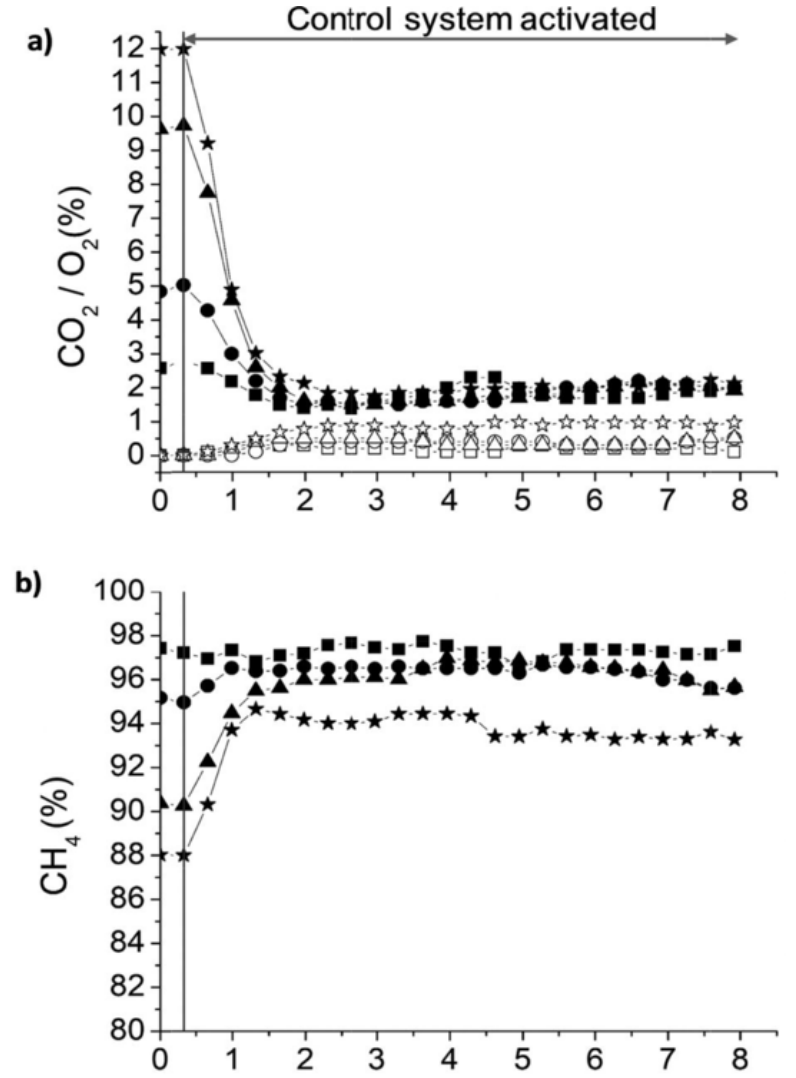

c)

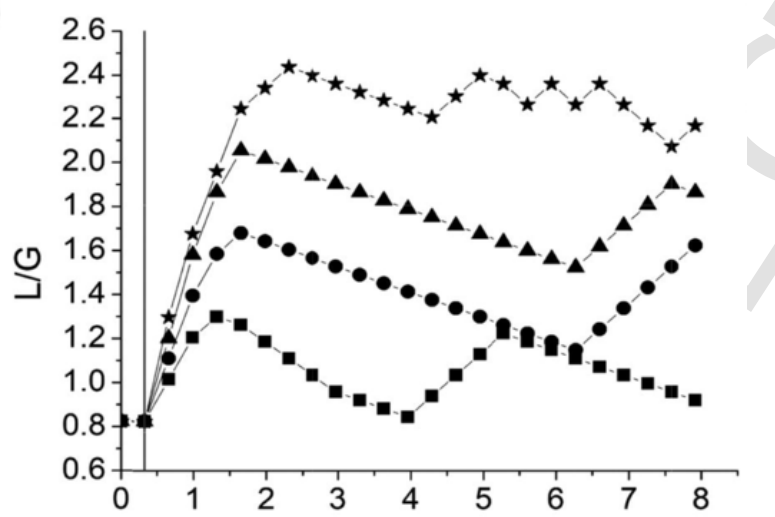

d)

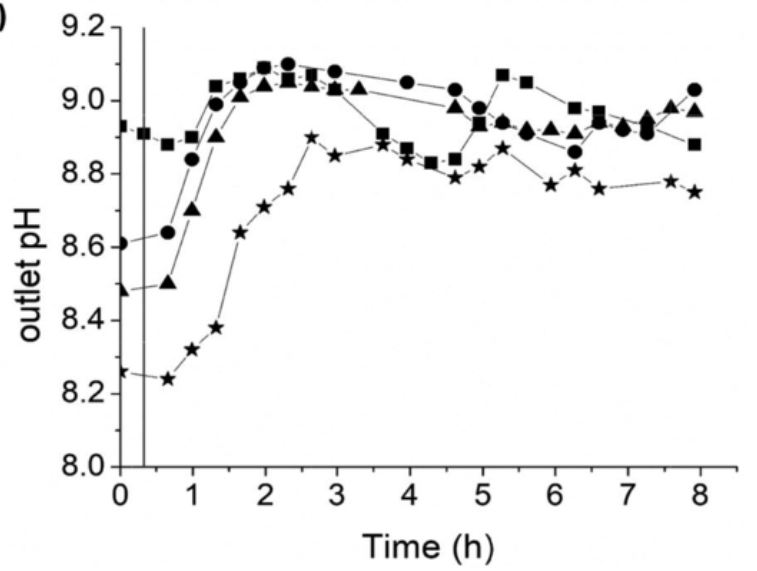

Fig. 1. Time course of a) $\mathrm{CO}_{2}$ (solid) and $\mathrm{O}_{2}$ (open) concentrations in the upgraded biogas, b) $\mathrm{CH}_{4}$ concentration in the upgraded biogas, c) liquid to biogas (L/G) ratio in the absorption column and d) outlet $\mathrm{pH}$ of the recycling liquid in the absorption column at a pH of the cultivation broth of 9.50 (square), 9.35 (circle), 9.20 (triangle) and 9.05 (star).

of 9.50, 9.35, 9.20 and 9.05, respectively (Fig. 1c). In fact, a lower decrease in the $\mathrm{pH}$ along the $\mathrm{AC}$ was obtained when the control system was active $(0.2 \pm 0.1$ vs $0.7 \pm 0.1)$ due to process operation at higher $\mathrm{L} / \mathrm{G}$ ratios (Fig. 1d). This lower decrease in the $\mathrm{pH}$ at higher $\mathrm{L} / \mathrm{G}$ ratios was associated to the lower mass of $\mathrm{CO}_{2}$ transferred per recycling liquid volume (Table S1), which allowed to achieve higher $\mathrm{CO}_{2}$-REs (Posadas et al., 2017). In this context, the limited acidification of the liquid along the AC due to the higher $\mathrm{L} / \mathrm{G}$ ratios when the system was controlled resulted in higher $\mathrm{CO}_{2}$-REs. This was mediated by the equilibrium shift from $\mathrm{CO}_{2}$ to $\mathrm{HCO}_{3}{ }^{-}$and $\mathrm{CO}_{3}{ }^{-2}$, which supported higher gas-liquid $\mathrm{CO}_{2}$ concentration gradients.

\subsection{Process response to stepwise variations in biogas flowrate}

The daily production of biogas might vary as a result of changes in the feedstock mass flowrate or composition and temperature in the anaerobic digester, which directly impacts on the upgrading process (Kim and Lee, 2016; Theuerl et al., 2019). Fig. 2 shows the upgraded biogas composition and liquid flowrate in the AC under controlled and uncontrolled conditions during the stepwise variations in biogas flowrate from $143 \mathrm{~L} \mathrm{~h}^{-1}$ to 218,300 and 420 , and back to $143 \mathrm{~L} \mathrm{~h}^{-1}$.

The $\mathrm{CO}_{2}$ concentration in the upgraded biogas increased from 2.5 to $14.1 \%$, when the biogas flowrate was stepwise increased from 143 to 218, 300 and $420 \mathrm{~L} \mathrm{~h}^{-1}$ under uncontrolled conditions (at a constant liquid flowrate of $327 \mathrm{~L} \mathrm{~h}^{-1}$ ), which corresponded to a decrease in the L/ $\mathrm{G}$ ratio from 2.3 to 0.8 . These results were in accordance with Marín et al. (2019), who reported a decrease in the $\mathrm{CO}_{2}$ content from $9.6 \%$ to negligible values when increasing the $\mathrm{L} / \mathrm{G}$ ratio from 0.5 to 2.0. Subsequently, when the biogas flowrate was stepwise decreased from 420 to $300 \mathrm{~L} \mathrm{~h}^{-1}$, the $\mathrm{CO}_{2}$ concentration slightly increased up to $16.1 \%$ as a result of the previous acidification of the liquid remaining in the AC. Then, the concentration of $\mathrm{CO}_{2}$ gradually decreased to $6.0 \%$ at the lowest biogas flowrate of $143 \mathrm{~L} \mathrm{~h}^{-1}$ (Fig. 2a). The $\mathrm{O}_{2}$ and $\mathrm{H}_{2} \mathrm{~S}$ concentrations in the upgraded biogas were negligible in the absence of control strategy, while $\mathrm{CH}_{4}$ concentration was correlated to $\mathrm{CO}_{2}$ removal, with a maximum concentration of $97.6 \%$ at $143 \mathrm{~L} \mathrm{~h}^{-1}$ (at the beginning of the assay) and a minimum $\mathrm{CH}_{4}$ concentration in the upgraded biogas of 83.9\% at $300 \mathrm{~L} \mathrm{~h}^{-1}$ (after the decrease from $420 \mathrm{~L} \mathrm{~h}^{-1}$ ) (Fig. 2b). Overall, the system was not able to achieve a biomethane quality complying with most international standards $\left(\mathrm{CO}_{2}\right.$ content $\leq 2 \%$ and $\mathrm{CH}_{4}$ content $\geq 90 \%$ ) without control system.

Biomethane quality improved significantly when the control system was active. Indeed, the $\mathrm{CO}_{2}$ concentration recorded in the upgraded biogas reached a maximum of $2.4 \%$ ( $\sim 6.7$ times lower than that without control) and remained almost constant at $\sim 2 \%$ regardless the stepwise variations in biogas flowrate from $143 \mathrm{~L} \mathrm{~h}^{-1}$ to 218,300 and 420, and back to $143 \mathrm{~L} \mathrm{~h}^{-1}$ (Fig. 2a). A complete $\mathrm{H}_{2} \mathrm{~S}$ removal was achieved, while low $\mathrm{O}_{2}$ concentrations in the biomethane $(\leq 0.5 \%)$ were recorded even at the maximum $\mathrm{L} / \mathrm{G}$ ratio of 4.9 (corresponding to a liquid flowrate of $703 \mathrm{~L} \mathrm{~h}^{-1}$ ) (Fig. 2c). These high $\mathrm{L} / \mathrm{G}$ ratios occurred during the stepwise decrease in the biogas flowrate, since the liquid flowrates imposed by the control system were still high due to the culture broth acidification caused by the previous biogas flowrates. In this context, the lower $\mathrm{O}_{2}$ desorption recorded at higher L/G ratios compared to that reported in section 3.1, where the $\mathrm{O}_{2}$ concentration in the biomethane was $1 \%$ at a $\mathrm{pH}$ of 9.05 and a $\mathrm{L} / \mathrm{G}$ ratio of 2.3 , could be attributed to the higher liquid flowrate reached in the previous section $\left(967 \mathrm{~L} \mathrm{~h}^{-1}\right)$ and the lower biogas flowrate $\left(143\right.$ or $\left.218 \mathrm{~L} \mathrm{~h}^{-1}\right)$ in the present experiment, which supported a lower turbulence in the AC and a lower $\mathrm{O}_{2}$ gas-liquid mass transfer in this unit. In this context, tur- 


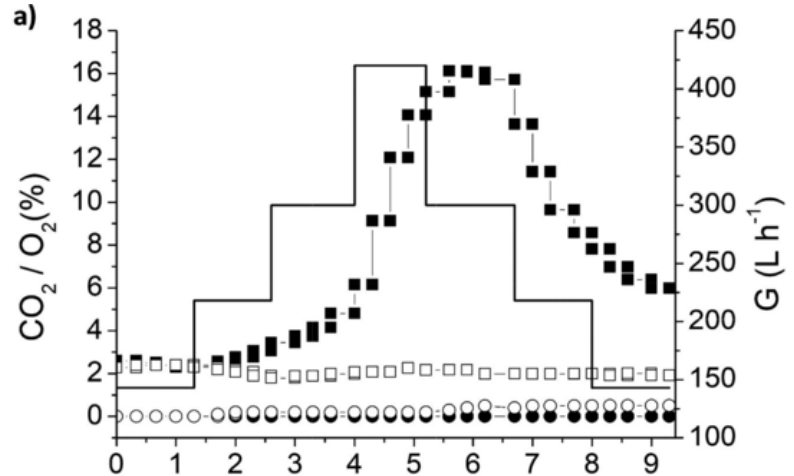

b)

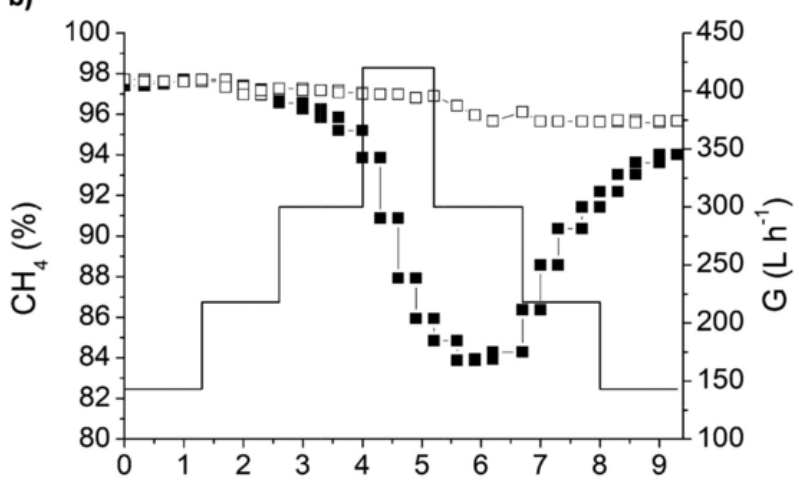

c)

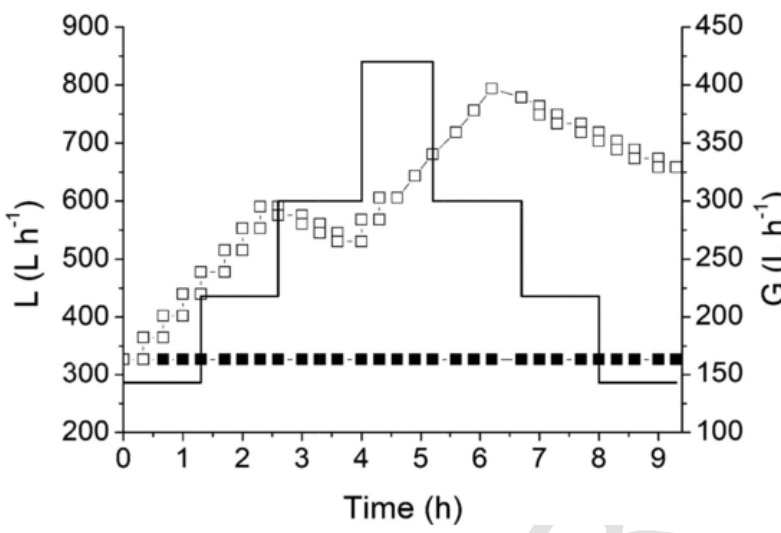

Fig. 2. Time course of a) $\mathrm{CO}_{2}$ (square) and $\mathrm{O}_{2}$ (circle) concentrations in the upgraded biogas, b) $\mathrm{CH}_{4}$ concentration in the upgraded biogas and c) liquid flowrate (L) under controlled (open) and uncontrolled (solid) conditions during the stepwise variation in biogas flowrate $(G)$ (continuous line).

bulence in the AC impacts on the average bubble size, which itself is inversely proportional to both components of the overall mass transfer coefficient $\left(\mathrm{k}_{1} \mathrm{a}\right)$ : the specific area (a) and the liquid transport coefficient $\left(\mathrm{k}_{1}\right)$ (Bordel et al., 2008). Finally, it should be stressed that the $\mathrm{CH}_{4}$ concentration in the upgraded biogas was $>95.5 \%$ during the complete experimental period under controlled conditions (Fig. 2b). In brief, the control strategy implemented was effective to cope with variations in the biogas flowrate over time.

\subsection{Robustness under operational failures in biogas supply and in the liquid} recirculation

Operational failures typically occur in biogas upgrading plants at full scale, which impacts on biomethane quality during the failure and/or afterwards when the system is restored. This requires the evaluation of the control system performance under the most relevant equipment failures in photosynthetic biogas upgrading (stoppage of biogas sup- ply or liquid recirculation). The upgraded biogas composition and liquid flowrate in the AC under controlled and uncontrolled conditions during a $2 \mathrm{~h}$ failure in biogas supply or liquid recirculation are shown in Figs. 3 and 4 , respectively.

Under uncontrolled conditions at a $\mathrm{L} / \mathrm{G}$ ratio of 1.1 , the $\mathrm{CO}_{2}$ concentration in the upgraded biogas accounted for $1.8 \pm 0.1 \%$ during the initial hours of the experiment assessing the robustness of the technology against a failure in biogas supply. The concentration of $\mathrm{CO}_{2}$ remained constant at $1.9 \%$ for the next $2 \mathrm{~h}$ without biogas supply (Fig. 3a), which could be attributed to the biomethane accumulated in an open to atmosphere gasometer located immediately after the biogas analyzer. Interestingly, the $\mathrm{CH}_{4}$ concentration was negatively impacted

a)

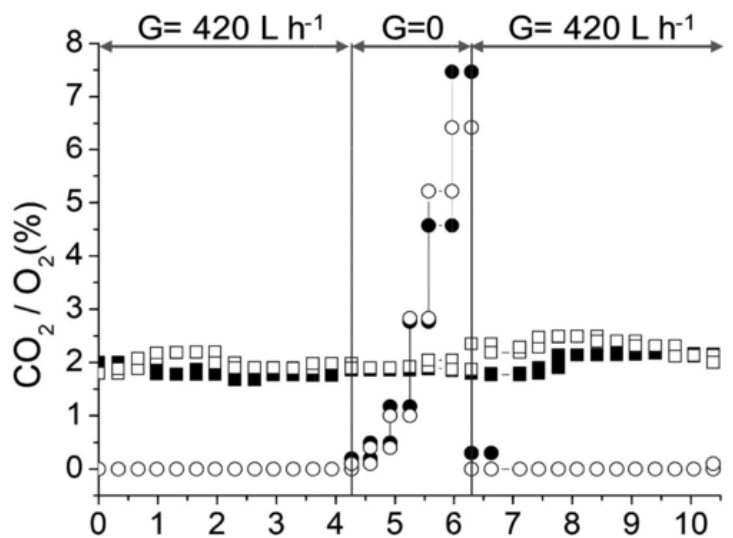

b)

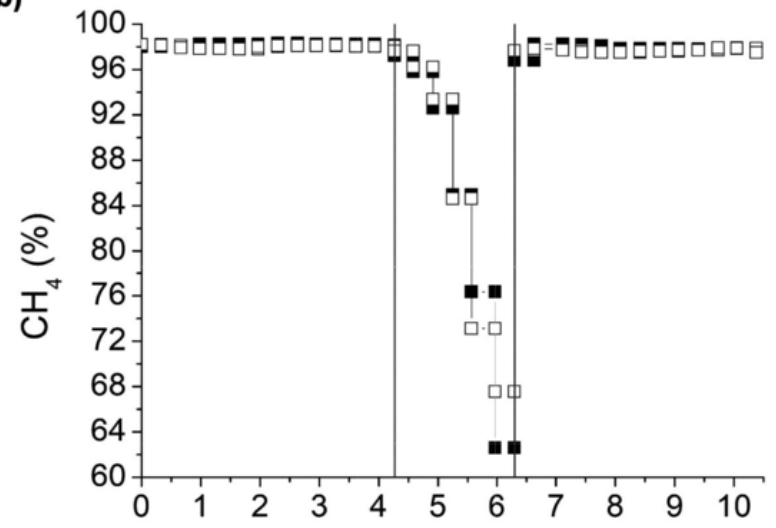

c)

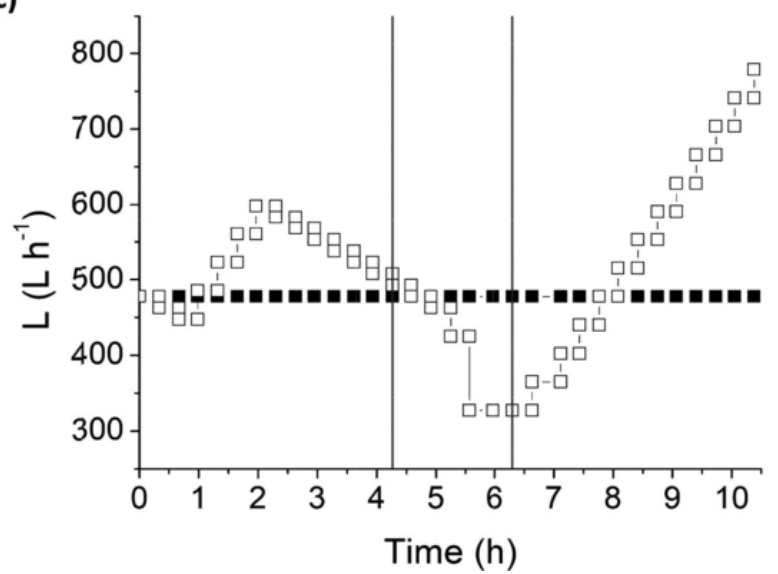

Fig. 3. Time course of a) $\mathrm{CO}_{2}$ (square) and $\mathrm{O}_{2}$ (circle) concentrations in the upgraded biogas, b) $\mathrm{CH}_{4}$ concentration in the upgraded biogas and c) liquid flowrate (L) under controlled (open) and uncontrolled (solid) conditions during a failure in biogas supply (G). 

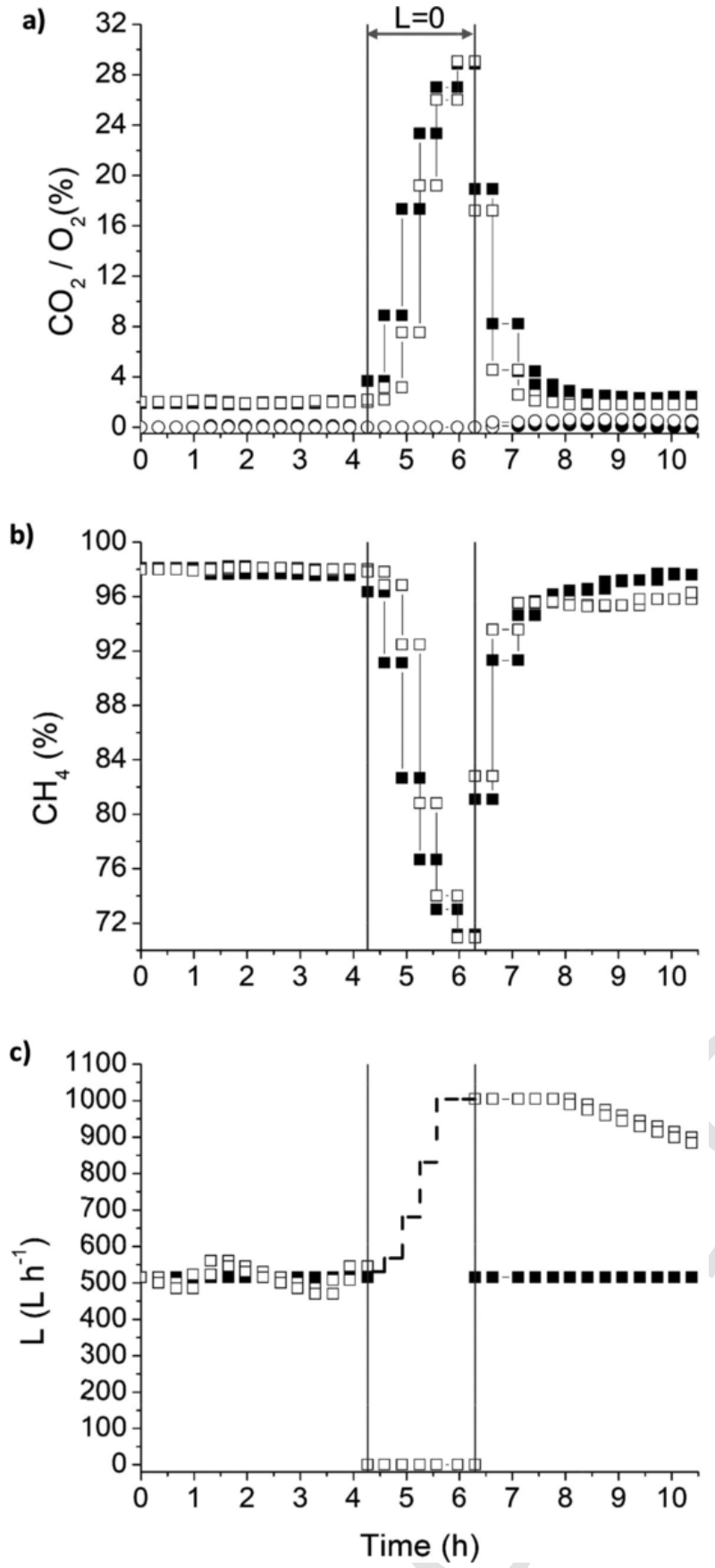

Fig. 4. Time course of a) $\mathrm{CO}_{2}$ (square) and $\mathrm{O}_{2}$ (circle) concentrations in the upgraded biogas, b) $\mathrm{CH}_{4}$ concentration in the upgraded biogas and c) liquid flowrate (L) under controlled (open) and uncontrolled (solid) conditions during a failure in liquid recirculation. The control system unit changes when the liquid pump was off are represented by a dashed line (c).

by the biogas compressor failure, decreasing from 98.1 to $62.6 \%$ after $2 \mathrm{~h}$ without biogas supply (Fig. 3b). This decrease can be explained by the entrance of air in the system, which was confirmed by the increase in $\mathrm{O}_{2}$ concentration up to $7.5 \%$ after $2 \mathrm{~h}$ (Fig. 3a). When biogas supply was re-started, the $\mathrm{O}_{2}$ concentration rapidly decreased to $0.3 \%$ within $20 \mathrm{~min}$, with an associated increase in $\mathrm{CH}_{4}$ concentration up to $96.8 \%, \mathrm{CO}_{2}$ concentrations $\sim 1.8 \%$ and no $\mathrm{H}_{2} \mathrm{~S}$ detected (Fig. 3a, b). This rapid increase in $\mathrm{CH}_{4}$ content was mediated by the high biogas flowrate used during this experiment $\left(420 \mathrm{~L} \mathrm{~h}^{-1}\right)$, which flushed the air out of the system. However, the $\mathrm{CO}_{2}$ concentration slightly increased to $\sim 2.2 \%$ following $1.5 \mathrm{~h}$ from the restoration of biogas supply (due to a slight decrease in the $\mathrm{pH}$ of the cultivation broth) and remained constant afterwards.

When the control system was initiated, the liquid flowrate fluctuated between 448 and $598 \mathrm{~L} \mathrm{~h}^{-1}$ during the first hours of experiment in order to maintain biomethane quality under optimal conditions in terms of energy consumption (Fig. 3a, c). The $\mathrm{CO}_{2}$ content in the absence of biogas supply remained constant at $\sim 1.9 \%$, while an increase in the $\mathrm{O}_{2}$ concentration from 0 to $6.4 \%$ was recorded as a result of air entrance, similar to that observed without control system (Fig. 3a). Thus, the control system decreased the liquid flowrate down to the minimum value $\left(327 \mathrm{~L} \mathrm{~h}^{-1}\right)$ in order to prevent a high $\mathrm{O}_{2}$ content in the upgraded biogas. In this context, when biogas supply was restarted, $\mathrm{CO}_{2}$ concentration in the upgraded biogas increased up to $2.5 \%$ as a result of the low liquid flowrate. Nevertheless, the system was able to decrease the $\mathrm{CO}_{2}$ concentration to $2 \%$ by the end of the experiment by imposing a liquid flowrate of $779 \mathrm{~L} \mathrm{~h}^{-1}$ (Fig. 3a, c). The $\mathrm{CH}_{4}$ concentration in the biomethane decreased from 98.0 to $67.5 \%$ in the absence of biogas supply, increasing to $97.7 \%$ within only $20 \mathrm{~min}$ after the resumption of biogas supply (Fig. 3b). $\mathrm{No}_{2} \mathrm{~S}$ was detected in the upgraded biogas along the experiment under controlled conditions. Overall, similar results were obtained under controlled and uncontrolled conditions, the system without control being even more effective when biogas supply was restarted. However, in case of an eventual increase in the $\mathrm{CO}_{2}$ content resulting from any variation in the cultivation broth, the system would not be able to recover the initial $\mathrm{CO}_{2}$ concentration without control.

$\mathrm{CO}_{2}$ content in the upgraded biogas remained constant at $1.9 \pm 0.1 \%$ during the first hours under uncontrolled conditions at a L/ $\mathrm{G}$ of 1.2 in the experiment assessing the robustness of the technology against a shutdown in the liquid supply to the AC. When the recirculating liquid pump was turned off, $\mathrm{CO}_{2}$ concentration in the upgraded biogas rapidly increased up to $28.9 \%$ within $2 \mathrm{~h}$, which almost matched the $\mathrm{CO}_{2}$ concentration of the raw biogas $(31.5 \pm 1.1 \%)$. This poor $\mathrm{CO}_{2}-\mathrm{RE}$ was due to the acidification and $\mathrm{CO}_{2}$ saturation of the liquid present in the biogas AC. However, the $\mathrm{CO}_{2}$ concentration in the upgraded biogas rapidly decreased when the liquid pump was turned on since the liquid retention time in the $\mathrm{AC}$ was only $17.5 \mathrm{~min}$ under the working liquid flowrate $\left(515 \mathrm{~L} \mathrm{~h}^{-1}\right)$. Unfortunately, the system was not able to recover the initial biomethane quality, with $\mathrm{CO}_{2}$ concentrations of $2.3 \%$ after approximately $2.5 \mathrm{~h}$ from liquid supply restoration (Fig. 4a). On the other hand, the $\mathrm{CH}_{4}$ content in the upgraded biogas decreased from 97.9 to $71.1 \%$ and increased up to $97.7 \%$ when the liquid pump was restarted (Fig. 4b). Despite the acidification of the scrubbing solution during the period without liquid renewal in the AC, negligible $\mathrm{H}_{2} \mathrm{~S}$ concentrations $\left(1 \mathrm{ppm}_{\mathrm{V}}\right)$ were detected as a result of its low concentration in the raw biogas. Finally, no significant $\mathrm{O}_{2}$ concentrations $(<0.2 \%)$ were recorded in the upgraded biogas along this experiment.

When the control system was active, minor variations in the liquid flowrate were recorded $\left(470-560 \mathrm{~L} \mathrm{~h}^{-1}\right)$ and the $\mathrm{CO}_{2}$ content remained below $2 \%$ (Fig. $4 \mathrm{a}, \mathrm{c}$ ). When the liquid recirculation was stopped, the $\mathrm{CO}_{2}$ concentration in the upgraded biogas increased up to $29.1 \%$, but no $\mathrm{H}_{2} \mathrm{~S}$ was detected as under uncontrolled conditions (Fig. 4a). The control system sent control actions of increasing the liquid flowrate $\left(\mathrm{CO}_{2}\right.$ measured $>\mathrm{CO}_{2}$ set point and $\left.\mathrm{O}_{2} \approx 0\right)$ during the period with no liquid supply since it was not able to detect the liquid pump failure. Therefore, when the liquid pump was switched on, the liquid flowrate imposed by the control system corresponded to the maximum pump flowrate $\left(\sim 1000 \mathrm{~L} \mathrm{~h}^{-1}\right)$. This entailed a decrease in the $\mathrm{CO}_{2}$ content of the upgraded biogas faster than under uncontrolled conditions due to the higher L/G ratio (2.4 vs 1.2 ) (Fig. 4c). However, the decrease in the $\mathrm{CO}_{2}$ content could have been even faster if higher pumping capacity would be available. On the other hand, the $\mathrm{O}_{2}$ content in the upgraded biogas increased when the liquid pump was turned on as a re- 
sult of the high liquid flowrate, but remained always below $1 \%$. Finally, the $\mathrm{CH}_{4}$ content in the upgraded biogas decreased from 98.0 to $70.9 \%$ due to the negligible $\mathrm{CO}_{2}$-REs in the absence of liquid recirculation. Nevertheless, $\mathrm{CH}_{4}$ content rapidly increased up to $95.8 \%$ when the liquid supply was restored although this value was lower compared to process operation without control system. This decrease was mediated by the higher $\mathrm{O}_{2}$ and $\mathrm{N}_{2}$ desorption from the recycling liquid to the biomethane as a result of the higher recycling liquid flowrate. Overall, the control system was able to provide a satisfactory biomethane quality in the event of a liquid supply stoppage, while in the absence of control system the $\mathrm{CO}_{2}$ concentration remained $>2 \%$ after liquid supply restoration.

\section{Conclusions}

The control system based on changes in the recycling liquid flowrate was able to meet the target biomethane quality $\left(\mathrm{CO}_{2}<2 \%\right.$ and $\mathrm{O}_{2}<1 \%$ ) regardless of the $\mathrm{pH}$ and biogas flowrate. Despite the poor robustness of this technology against failures in biogas and liquid supply was confirmed, the control system restored the biomethane quality satisfactorily after the event of a stoppage in biogas supply and liquid recirculation. This control strategy validated in an outdoors semi-industrial scale photobioreactor would overcome the negative effects of environmental variations or operational failures on photosynthetic biogas upgrading performance, ensuring a consistent biomethane quality.

\section{CRediT authorship contribution statement}

María del Rosario Rodero: Investigation, Methodology, Data curation, Writing - original draft. Andrea Carvajal: Conceptualization, Methodology, Data curation. Zouhayr Arbib: Project administration, Resources. Enrique Lara: Project administration, Resources. César de Prada: Methodology, Software. Raquel Lebrero: Conceptualization, Funding acquisition, Supervision, Writing - review \& editing. Raúl Muñoz: Conceptualization, Funding acquisition, Supervision, Writing review \& editing.

\section{Declaration of Competing Interest}

The authors declare that they have no known competing financial interests or personal relationships that could have appeared to influence the work reported in this paper.

\section{Acknowledgements}

This work was supported by the INCOVER project. The project has received funding from the European Union's Horizon 2020 research and innovation programme under grant agreement No. 689242. Maikel Fernández, Esteban Serrano, Almudena Barea, Jose Antonio Macías, Ezequiel García and Esther Arnáiz are gratefully acknowledged for their practical assistance. The regional government of Castilla y León and the European FEDER Programme (CLU 2017-09 and UIC 071) is also gratefully acknowledged.

\section{Appendix A. Supplementary data}

Supplementary data to this article can be found online at https://doi. org/10.1016/j.biortech.2020.123207.

\section{References}

Angelidaki, I, Treu, L, Tsapekos, P, Luo, G, Campanaro, S, Wenzel, H, Kougias, P G, 2018. Biogas upgrading and utilization: current status and perspectives. Biotechnol. Adv. 36 (2), 452-466. doi:10.1016/j.biotechadv.2018.01.011.

Awe, O W, Yaqian, Z, Ange, N, Doam Pham, M, Nathalie, L, 2017. A review of biogas utilisation, purification and upgrading technologies. Waste Biomass Valoriz. 8, 267-283. doi:10.1007/s12649-016-9826-4.
Bahr, M, Díaz, I, Dominguez, A, González Sánchez, A, Muñoz, R, 2014. Microalgal-biotechnology as a platform for an integral biogas upgrading and nutrient removal from anaerobic effluents. Environ. Sci. Technol. 48, 573-581. doi:10.1021/ es $403596 \mathrm{~m}$.

Bordel, S, Muñoz, R, Díaz, L F, Villaverde, S, 2008. Mechanistic model for evaluating the performance of suspended growth bioreactors for the off-gas treatment of VOCs. Biochem. Eng. J. 38, 395-405. doi:10.1016/j.bej.2007.08.004.

Bose, A, Lin, R, Rajendran, K, O'Shea, R, Xia, A, Murphy, J D, 2019. How to optimise photosynthetic biogas upgrading: a perspective on system design and microalgae selection. Biotechnol. Adv. 107444. doi:10.1016/j.biotechadv.2019.107444.

Brito, J, Almenglo, F, Ramírez, M, Gómez, J M, 2017. PID control system for biogas desulfurization under anoxic conditions. J. Chem. Technol. Biotechnol. 92, 2369-2375. doi:10.1002/jctb.5243.

de Godos, I, Arbib, Z, Lara, E, Rogalla, F, 2016. Evaluation of High Rate Algae Ponds for treatment of anaerobically digested wastewater: effect of $\mathrm{CO}_{2}$ addition and modification of dilution rate. Bioresour. Technol. 220, 253-261. doi:10.1016/ j.biortech.2016.08.056

Di Benedetto, A, Cammarota, F, Di Sarli, V, Salzano, E, Russo, G, 2011. Anomalous behavior during explosions of $\mathrm{CH}_{4}$ in oxygen-enriched air. Combust. Flame 158, 2214-2219. doi:10.1016/j.combustflame.2011.03.015.

Directive (EU) 2018/2001, 2018. Directive (EU) 2018/2001 of the European Parliament and of the Council on the promotion of the use of energy from renewable sources, Official J. Eur. Union.

EBA, 2018. European Biogas Association Statistical Report 2018.

Franco-Morgado, M, Alcántara, C, Noyola, A, Muñoz, R, González-Sánchez, A, 2017. A study of photosynthetic biogas upgrading based on a high rate algal pond under alkaline conditions: Influence of the illumination regime. Sci. Total Environ. 592, 419-425. doi:10.1016/j.scitotenv.2017.03.077.

Kang, J, Yoon, Y, Song, J, 2020. Effects of $\mathrm{pH}$ on the simultaneous removal of hydrogen sulfide and ammonia in a combined absorption and electro-oxidation system. J. Hazard. Mater. 382, 121011. doi:10.1016/j.jhazmat.2019.121011.

Kim, J, Lee, C, 2016. Response of a continuous anaerobic digester to temperature transitions: a critical range for restructuring the microbial community structure and function. Water Res. 89, 241-251. doi:10.1016/j.watres.2015.11.060.

Lee, Y K, Pirt, S J, 1984. $\mathrm{CO}_{2}$ absorption rate in an algal culture: effect of pH. J. Chem. Technol. Biotechnol. Biotechnol. 34 (B), 28-32. doi:10.1002/jctb.280340105.

Marín, D, Ortíz, A, Díez-Montero, R, Uggetti, E, García, J, Lebrero, R, Muñoz, R, 2019. Influence of liquid-to-biogas ratio and alkalinity on the biogas upgrading performance in a demo scale algal-bacterial photobioreactor. Bioresour. Technol. 280, 112-117. doi:10.1016/j.biortech.2019.02.029.

Marín, D, Posadas, E, Cano, P, Pérez, V, Blanco, S, Lebrero, R, Muñoz, R, 2018. Seasonal variation of biogas upgrading coupled with digestate treatment in an outdoors pilot scale algal-bacterial photobioreactor. Bioresour. Technol. 263, 58-66. doi:10.1016/ j.biortech.2018.04.117.

Meier, L, Martínez, C, Vílchez, C, Bernard, O, Jeison, D, 2019. Evaluation of the feasibility of photosynthetic biogas upgrading: simulation of a large-scale system. Energy 116313. doi:10.1016/j.energy.2019.116313.

Meier, L, Stará, D, Bartacek, J, Jeison, D, 2018. Removal of $\mathrm{H}_{2} \mathrm{~S}$ by a continuous microalgae-based photosynthetic biogas upgrading process. Process Saf. Environ. Prot 119, 65-68. doi:10.1016/j.psep.2018.07.014.

Muñoz, R, Meier, L, Díaz, I, Jeison, D, 2015. A review on the state-of-the-art of physical/ chemical and biological technologies for biogas upgrading. Rev. Environ. Sci. Bio/ Technol. 14, 727-759. doi:10.1007/s11157-015-9379-1.

Nagarajan, D, Lee, D-J, Chang, J-S, 2019. Integration of anaerobic digestion and microalgal cultivation for digestate bioremediation and biogas upgrading. Bioresour. Technol. 290, 121804. doi:10.1016/j.biortech.2019.121804.

Ouyang, Y, Zhao, Y, Sun, S, Hu, C, Ping, L, 2015. Effect of light intensity on the capability of different microalgae species for simultaneous biogas upgrading and biogas slurry nutrient reduction. Int. Biodeterior. Biodegrad. 104, 157-163. doi:10.1016 j.ibiod.2015.05.027.

Posadas, E, Marín, D, Blanco, S, Lebrero, R, Muñoz, R, 2017. Simultaneous biogas upgrading and centrate treatment in an outdoors pilot scale high rate algal pond. Bioresour. Technol. 232, 133-141. doi:10.1016/j.biortech.2017.01.071.

Rodero, Mdel R, Carvajal, A, Castro, V, Navia, D, de Prada, C, Lebrero, R, Muñoz, R, 2019. Development of a control strategy to cope with biogas flowrate variations during photosynthetic biogas upgrading. Biomass Bioenergy 131, 105414. doi:10.1016/ j.biombioe.2019.105414.

Rodero, Mdel R, Posadas, E, Toledo-Cervantes, A, Lebrero, R, Muñoz, R, 2018. Influence of alkalinity and temperature on photosynthetic biogas upgrading efficiency in high rate algal ponds. Algal Res. 33, 284-290. doi:10.1016/j.algal.2018.06.001.

Ryckebosch, E, Drouillon, M, Vervaeren, H, 2011. Techniques for transformation of biogas to biomethane. Biomass Bioenergy 35, 1633-1645. doi:10.1016/ j.biombioe.2011.02.033.

Sander, R., 1999. Compilation of Henry's Law Constants for Inorganic and Organic Species of Potential importance in Environmental Chemistry.

Serejo, M L, Posadas, E, Boncz, M A, Blanco, S, García-Encina, P, Muñoz, R, 2015. Influence of biogas flow rate on biomass composition during the optimization of biogas upgrading in microalgal-bacterial processes. Environ. Sci. Technol. 49, 3228-3236. doi:10.1021/es5056116.

Smet, E, Lens, P, Langenhove, H Van, 1998. Treatment of waste gases contaminated with odorous sulfur compounds. Crit. Rev. Environ. Sci. Technol. 28, 89-117.

Sun, S, Ge, Z, Zhao, Y, Hu, C, Zhang, H, Ping, L, 2016. Performance of $\mathrm{CO}_{2}$ concentrations on nutrient removal and biogas upgrading by integrating microalgal strains cultivation with activated sludge. Energy 97, 229-237. doi:10.1016/j.energy.2015.12.126.

Surendra, K C, Takara, D, Hashimoto, A G, Khanal, S K, 2014. Biogas as a sustainable energy source for developing countries: opportunities and challenges. Renew. Sustain. Energy Rev. 31, 846-859. doi:10.1016/j.rser.2013.12.015. 
Theuerl, S, Klang, J, Prochnow, A, 2019. Process disturbances in agricultural biogas production - causes, mechanisms and effects on the biogas microbiome: a review. Energies 12. doi:10.3390/en12030365.

Toledo-Cervantes, A, Madrid-Chirinos, C, Cantera, S, Lebrero, R, Muñoz, R, 2017. Influence of the gas-liquid flow configuration in the absorption column on photosynthetic biogas upgrading in algal-bacterial photobioreactors. Bioresour. Technol. 225, 336-342. doi:10.1016/j.biortech.2016.11.087.
Toledo-Cervantes, A, Serejo, M L, Blanco, S, Pérez, R, Lebrero, R, Muñoz, R, 2016. Photosynthetic biogas upgrading to bio-methane: boosting nutrient recovery via biomass productivity control. Algal Res. 17, 46-52. doi:10.1016/j.algal.2016.04.017.

Yan, C, Zhu, L, Wang, Y, 2016. Photosynthetic $\mathrm{CO}_{2}$ uptake by microalgae for biogas upgrading and simultaneously biogas slurry decontamination by using of microalgae photobioreactor under various light wavelengths, light intensities, and photoperiods. Appl. Energy 178, 9-18. doi:10.1016/j.apenergy.2016.06.012. 